Patterson, M. M., \& Pahlke, E. (2011). Student Characteristics Associated With Girls' Success in a Single-Sex School. Sex Roles, 65, 737-750. Publisher's official version: http://dx.doi.org/10.1007/s11199-010-9904-1.

Open Access version: http://kuscholarworks.ku.edu/dspace/.

[This document contains the author's accepted manuscript. For the publisher's version, see the link in the header of this document.]

\title{
Student Characteristics Associated With Girls' Success in a Single-Sex School
}

\author{
By Meagan M. Patterson and Erin Pahlke
}

\author{
Paper citation: \\ Patterson, M. M., \& Pahlke, E. (2011). Student Characteristics Associated With Girls’ Success in \\ a Single-Sex School. Sex Roles, 65, 737-750.
}

\author{
Keywords: \\ single-sex education, gender, achievement, stereotyping
}

\begin{abstract}
:
Given the mixed results of previous studies on the benefits of single-sex schooling, scholars have called for research on differences in the effects of single-sex schooling based on student and school characteristics. We sought to examine the associations of a range of student characteristics with attitudes and achievement among students attending an all-girls public middle school in the southwestern United States. Predictor variables included demographic factors (i.e., race, family income), prior academic achievement, gender stereotyping, and gender identity (i.e., gender typicality, peer preferences). Prior academic achievement predicted later achievement and persistence in the single-sex school. School-related stereotyping was associated with success in and connection to the single-sex school; school connection was also a significant moderator of the relation between stereotyping and academic performance. Gendertyped peer preferences were associated with school connection and persistence. Overall, results indicate that student characteristics, as well as issues of "fit" with the specific school, are associated with students' connection to and success in single-sex educational environments.
\end{abstract}


Patterson, M. M., \& Pahlke, E. (2011). Student Characteristics Associated With Girls' Success in a Single-Sex School. Sex Roles, 65, 737-750. Publisher's official version: http://dx.doi.org/10.1007/s11199-010-9904-1.

Open Access version: http://kuscholarworks.ku.edu/dspace/.

Student Characteristics Associated With Girls' Success in a Single-Sex School

Meagan M. Patterson

University of Kansas

Erin Pahlke

Arizona State University 
Patterson, M. M., \& Pahlke, E. (2011). Student Characteristics Associated With Girls' Success in a Single-Sex School. Sex Roles, 65, 737-750. Publisher's official version: http://dx.doi.org/10.1007/s11199-010-9904-1.

Open Access version: http://kuscholarworks.ku.edu/dspace/.

\section{Introduction}

Single-sex schools are common in many countries, such as Australia, Belgium, New Zealand, and Saudi Arabia (Australian Bureau of Statistics, 1997; Baker, Riordan, \& Schaub, 1995; Baki, 2004), but are relatively rare in the United States. However, in recent years there has been increasing interest in single-sex schooling in the United States (Thompson \& Ungerleider, 2004). According to the National Association for Single-Sex Public Education, there are currently over 90 single-sex public schools in the United States and more than 400 additional public schools that offer single-sex classes (NASSPE, 2010). Findings of empirical research on outcomes in single-sex versus coeducational environments have been mixed; based in part on these mixed results, some educators and researchers have argued that single-sex schools may be beneficial for some- but not other—students. The purpose of the present study was to examine whether individual differences among students were predictive of their success within a public, single-sex middle school. Predictor variables included demographic factors, prior academic achievement, gender stereotyping, and gender identity. We examined the utility of these variables for predicting each of three outcomes: perceptions of school connection, academic performance, and persistence (i.e., whether the student continued to attend the singlesex school).

Despite the recent wave of interest in public single-sex schooling in the United States, research on the overall effectiveness of single-sex schools has generally focused on private schools (e.g., Lee \& Bryk, 1986; Riordan, 2002) or public schools in educational systems that are meaningfully different from the American system (e.g., Nigeria, Northern Ireland, Thailand; Cairns, 1990; Jimenez \& Lockheed, 1989; Lee \& Lockheed, 1990). Little research has examined the effectiveness of American public single-sex schools as compared to similar coeducational 
Patterson, M. M., \& Pahlke, E. (2011). Student Characteristics Associated With Girls' Success in a Single-Sex School. Sex Roles, 65, 737-750. Publisher's official version: http://dx.doi.org/10.1007/s11199-010-9904-1. Open Access version: http://kuscholarworks.ku.edu/dspace/.

schools; arguments for the efficacy of single-sex public schools are often based on assumptions about gender differences in learning styles or the efficacy of gender segregation for decreasing classroom disruptions (Barnett \& Rivers, 2004; Gurian, 2001; Sax, 2005). Proponents of singlesex education argue that single-sex programs are superior to coeducational programs in terms of student achievement, student attitudes, and school climate (Lee \& Bryk, 1986, 1989; Riordan, 1994, 2002; Streitmatter, 1999). Opponents of single-sex education argue that single-sex programs are no more effective academically than coeducational programs and may have negative impacts on students’ attitudes or gender stereotyping (Campbell \& Sanders, 2002; Datnow, Hubbard, \& Woody, 2001; Signorella, Frieze, \& Hershey, 1996).

Findings of empirical research on outcomes in single-sex versus coeducational environments have been mixed, with some studies finding improved outcomes in single-sex environments (Lee \& Bryk, 1986, 1989; Riordan, 1994, 2002; Streitmatter, 1999), others finding no advantages (LePore \& Warren, 1997; Shmurak, 1998; Wood \& Brown, 1997), and still others finding mixed results (AAUW, 1998; Bracey, 2006; Mael, 1998; Singh, Vaught, \& Mitchell, 1998; U.S. Department of Education, 2005). Thus, scholars in the field have called for research examining whether the efficacy of single-sex schooling varies as a function of student characteristics such as gender, age, race, and socioeconomic status (Mael, 1998; Salomone, 2006).

In the present study, we examined several social group and individual differences that might predict students' success within an all-girls school in the southwestern United States. The first set of predictors included demographic factors such as family income and race. The second set of predictors included indices of prior academic achievement, including reading and math standardized test scores. The third set of predictors examined the effects of gender stereotype 
Patterson, M. M., \& Pahlke, E. (2011). Student Characteristics Associated With Girls' Success in a Single-Sex School. Sex Roles, 65, 737-750. Publisher's official version: http://dx.doi.org/10.1007/s11199-010-9904-1.

Open Access version: http://kuscholarworks.ku.edu/dspace/.

endorsement. The fourth set of predictors examined the effects of gender identity variables (i.e., gender typicality and peer preferences).

\section{Socioeconomic Status}

Some researchers have proposed that single-sex schools are particularly beneficial for students from economically disadvantaged backgrounds. Support for this hypothesis comes from a series of studies that indicated advantages of single-sex over coeducational environments in private Catholic schools, but not independent (i.e., non-religious) private schools (Lee, 1998; Lee \& Bryk, 1986; Lee \& Marks, 1990; Lee, Marks, \& Byrd, 1994). Lee and colleagues have proposed that these findings may be explained by socioeconomic differences between students who attend Catholic schools, which are typically fairly inexpensive and thus draw students from a range of economic backgrounds, and students who attend independent private schools, which are typically expensive and thus draw students primarily from economically advantaged backgrounds. This and other research has led some scholars to conclude that there is a meaningful positive impact of attending a single-sex school among economically disadvantaged, but not economically advantaged, students (Riordan, 1990, 2002).

We tested whether individual differences in socioeconomic status were associated with student success within a single-sex school context. We predicted that, as in coeducational schools, family income level would be positively related to academic performance (hypothesis 1a). We did not, however, expect that family income status would be associated with students' connection to or persistence at the single-sex school.

\section{Race}

The resurgence of interest in single-sex schools has focused primarily on students of color, particularly African American and Latino students from economically disadvantaged 
Patterson, M. M., \& Pahlke, E. (2011). Student Characteristics Associated With Girls' Success in a Single-Sex School. Sex Roles, 65, 737-750. Publisher's official version: http://dx.doi.org/10.1007/s11199-010-9904-1. Open Access version: http://kuscholarworks.ku.edu/dspace/.

backgrounds (Gewertz, 2007; Riordan, 1994; Salomone, 2006). Riordan (1994) has argued that single-sex schools may be especially beneficial for African American and Latino students because the single-sex schools that serve predominately minority students have positive characteristics, such as an academically-focused school culture and strict discipline, that tend to be lacking in public coeducational schools that serve these populations.

Results of some empirical studies have been less positive, however. For example, Jayaratne, Thomas, and Trautman (2003) found that whereas European American girls who participated in an all-girls science enrichment program showed higher interest in science compared to girls who had not participated, minority girls who participated showed less interest in science than girls who had not participated. In addition, it is often difficult to separate the effects of race and ethnicity from the effects of socioeconomic variables that are correlated with race and ethnicity. Thus, one must be cautious in interpreting findings of racial or ethnic differences in students’ success within single-sex environments.

We tested whether students’ racial and ethnic background was associated with students’ attitudes toward and success within a single-sex school context. We predicted that, consistent with the persistent racial/ethnic education gaps in the United States (Planty et al., 2009), African American and Latina students would show poorer academic performance than their Asian American and European American peers (hypothesis 2a).

\section{Prior Academic Achievement}

A number of proponents of single-sex schools have argued that a major advantage of such schools is their strong academic orientation (Lee, 1998; Riordan, 1990, 1994). To the extent that single-sex schools have a strong academic orientation, students’ prior academic achievement is likely to influence their attitudes toward and success in single-sex schools. 
Patterson, M. M., \& Pahlke, E. (2011). Student Characteristics Associated With Girls' Success in a Single-Sex School. Sex Roles, 65, 737-750. Publisher's official version: http://dx.doi.org/10.1007/s11199-010-9904-1. Open Access version: http://kuscholarworks.ku.edu/dspace/.

We tested whether individual differences in prior academic achievement were associated with student success within a single-sex school context. The mission of the single-sex school being studied included a focus on academics, particularly science, technology, math, and engineering (STEM) careers, and on promoting leadership. We predicted that those girls with greater prior achievement in these domains (e.g., math) would show greater satisfaction with, success in, and persistence at the school than those girls with poorer prior achievement in these domains (hypotheses 3a, 3b, and 3c).

\section{Gender Stereotyping}

Some research has examined the role of stereotyping within the single-sex schooling environment, but typically as an outcome rather than a predictor variable (Gwizdala \& Steinback, 1990; Harris, 1986; Jimenez \& Lockheed, 1990; Lee et al., 1994; Signorella et al., 1996). Researchers have not typically examined questions regarding the effects of students’ initial gender stereotypes on their satisfaction with or success in single-sex environments. To the extent that the single-sex school environment reinforces traditional gender roles (e.g., a girls’ school emphasizing cooperation over competition), students with traditional gender role attitudes should react more positively to single-sex environments than students with egalitarian attitudes. However, to the extent that the single-sex environment provides alternatives to traditional gender roles (e.g., promotes participation in activities typically reserved for the other gender), students with egalitarian gender role attitudes should react more positively to single-sex environments than students with traditional gender role attitudes. In the current study we examined these conflicting hypotheses by examining the relations among endorsement of gender stereotypes and perceptions of connection to a single-sex environment (exploratory test $4 a$ ). 
Patterson, M. M., \& Pahlke, E. (2011). Student Characteristics Associated With Girls' Success in a Single-Sex School. Sex Roles, 65, 737-750. Publisher's official version: http://dx.doi.org/10.1007/s11199-010-9904-1.

Open Access version: http://kuscholarworks.ku.edu/dspace/.

A second, related question is whether gender stereotypes influence students' academic performance. Although a number of theories predict relations between stereotype endorsement and interest in gender stereotyped domains (e.g., Liben \& Bigler, 2002; Wigfield \& Eccles, 2000), relatively few studies have examined relations between stereotype endorsement and students' actual performance. Of these, some studies report endorsement of gender stereotypes about STEM fields to be negatively correlated with girls’ performance in these domains, as measured by grades or test scores (Boswell, 1985; Fennema \& Sherman, 1977, 1978). Other studies, however, have failed to find links between students' stereotype endorsement and their academic performance (Oakes, 1990). We predicted that endorsement of gender stereotypes in school-related domains (e.g., science) would be related to students’ academic performance within and persistence at the single-sex school, with those students who were higher in gender stereotype endorsement having poorer grades and being less likely to continue attending the single-sex school than those students who were lower in gender stereotype endorsement (hypotheses $4 b$ and $4 c$ ).

\section{Gender Identity}

One argument for single-sex schools is that gender role norms at single-sex schools may be more flexible than those seen at coeducational schools (Caplice, 1994; Lee \& Bryk, 1986). Gender role norms and gender identity may be especially important among middle school students due to gender intensification processes in early adolescence (Galambos, Almeida, \& Petersen, 1990; Huston \& Alvarez, 1990). To the extent that they foster flexible gender norms, single-sex schools may be more accepting of students who do not conform to traditional gender roles than coeducational schools, and thus students with less traditional gender identities may have more positive attitudes toward and greater success in single-sex schools. However, it is 
Patterson, M. M., \& Pahlke, E. (2011). Student Characteristics Associated With Girls' Success in a Single-Sex School. Sex Roles, 65, 737-750. Publisher's official version: http://dx.doi.org/10.1007/s11199-010-9904-1. Open Access version: http://kuscholarworks.ku.edu/dspace/.

also possible that single-sex schools make gender more salient through the process of gender segregation (Bigler \& Liben, 2006; Patterson \& Bigler, 2007), or that single-sex schools have gender norms that are equally, or even more, rigid than those seen in coeducational environments (Harris, 1986; Lee et al., 1994; Signorella et al., 1996). In the current study, we examined the relations of two aspects of gender identity—gender typicality and preference for same- and other-sex peers — with students' attitudes toward and success in the single-sex environment.

Gender Typicality. Self-perceived gender typicality (i.e., one’s feelings or impressions of how typical one is of one's gender) is related to a number of aspects of adjustment, such as self-esteem (Egan \& Perry, 2001) and peer acceptance (Smith \& Leaper, 2005). Single-sex environments may serve to make gender typicality more salient than would be the case in mixedsex environments. In line with this hypothesis, recent research indicates that gender typicality may have a greater impact on adjustment in single-sex than coeducational schools (Drury, Bukowski, Saldarriaga, \& Santo, 2009). Drury and colleagues (2009) studied gender typicality among Colombian elementary school students and found that gender typicality was more strongly associated with perceived peer acceptance for girls at a single-sex school than girls at a coeducational school. Drury and colleagues conclude that the importance of gender typicality may be amplified in a single-sex educational environment (although these data are from a single cultural setting and therefore must be interpreted with some caution). In the current study, we predicted that higher levels of gender typicality would be related to more positive attitudes toward, greater success in, and greater persistence at the single-sex school (hypotheses $5 a, 5 b$, and 5c).

Preference for same- and other-gender friends. A common argument for single-sex schools is the widespread preference for interaction with same-gender over other-gender 
Patterson, M. M., \& Pahlke, E. (2011). Student Characteristics Associated With Girls' Success in a Single-Sex School. Sex Roles, 65, 737-750. Publisher's official version: http://dx.doi.org/10.1007/s11199-010-9904-1.

Open Access version: http://kuscholarworks.ku.edu/dspace/.

individuals (Mael, 1998). Indeed, children do demonstrate preferences for same-gender peers throughout childhood and early adolescence (Maccoby \& Jacklin, 1987; Ruble, Martin, \& Berenbaum, 2006). Some researchers have argued that these preferences are driven by gender differences in styles of interaction or play (Maccoby, 1998; Martin \& Fabes, 2001), whereas others have argued they are driven primarily by ingroup bias (Hoffman \& Powlishta, 2001; Liben \& Bigler, 2002; Powlishta, 1995, 2004). Children show biases in favor of members of their own gender groups on a variety of measures, including peer preference, from an early age (Arthur, Bigler, Liben, Gelman, \& Ruble, 2008; Martin \& Ruble, 2010; Powlishta, 1995; Ruble et al., 2006). We examined the association between students' existing friendships and friendship preferences and their success in and connection to a single-sex school. We predicted that girls who had fewer male friends and a greater interest in female friends would have more positive attitudes toward and greater success in the single-sex school than girls with more male friends or less interest in female friends (hypotheses 6a and 6b). Further, we predicted that girls who had few male friends and greater interest in female friends would be more likely to persist in the single-sex school (hypothesis 6c).

\section{School Climate and Connection to School}

School climate is the extent to which students have a sense of safety and belonging at their school; in a school with a positive climate students feel supported, encouraged, and accepted (Hansen \& Childs, 1998; Sherblom, Marshall, \& Sherblom, 2006). Perception of connection to school is one key element of school climate (Sherblom et al., 2006; Skiba et al., 2004). Students' experience of acceptance and belonging in their schools is associated with a number of outcomes, including school engagement and academic performance (Furrer \& Skinner, 2003; Osterman, 2000; Sherblom et al., 2006). 
Patterson, M. M., \& Pahlke, E. (2011). Student Characteristics Associated With Girls' Success in a Single-Sex School. Sex Roles, 65, 737-750. Publisher's official version: http://dx.doi.org/10.1007/s11199-010-9904-1. Open Access version: http://kuscholarworks.ku.edu/dspace/.

In a single-sex school, feelings of school connection are likely to be tied to students' beliefs about gender, including gender stereotype endorsement and the implications of stereotypes for the self. Thus, we examined students' perceptions of connection to the school both as an outcome variable (as discussed in previous hypotheses) and as a possible moderating variable in relation to academic performance. Specifically, we predicted that a sense of connection to the school would moderate the relation between stereotype endorsement and achievement (hypothesis 7a).

\section{The Present Study}

The purpose of the present study was to examine the utility of a set of characteristics for predicting student success among girls attending a public single-sex middle school. Predictor variables were race, family income status, prior academic achievement, gender stereotyping, gender typicality, and peer preferences. We examined the effects of each of these predictors on three outcomes: perceptions of school connection, academic performance (i.e., grades), and persistence (i.e., whether the student remained in or left the all-girls school).

Specifically, we tested the prediction that family income level would be positively related to academic performance (hypothesis 1a) and that African American and Latino students would perform more poorly than their Asian American and European American peers (hypothesis 2a). We also tested the prediction that girls with higher prior achievement in a domain emphasized at the single-sex school (i.e., math) would feel more connected to the school (hypothesis 3a) and that students with higher prior achievement would perform better at and persist more at the academically-rigorous school (hypotheses $3 b$ and $3 c$ ). With regard to gender stereotyping, we did not have an a priori hypothesis about the possible connection between gender stereotyping and connection to a single-sex school, but we tested the competing possible 
Patterson, M. M., \& Pahlke, E. (2011). Student Characteristics Associated With Girls' Success in a Single-Sex School. Sex Roles, 65, 737-750. Publisher's official version: http://dx.doi.org/10.1007/s11199-010-9904-1.

Open Access version: http://kuscholarworks.ku.edu/dspace/.

hypotheses (exploratory test 4a). We did make predictions about the connection between stereotypes, achievement, and persistence at the school. We predicted that endorsement of gender stereotypes, particularly in school-related domains (e.g., science), would be related to poorer grades and lower persistence levels (hypotheses $4 b$ and $4 c$ ). With regard to gender identity, we predicted that higher levels of gender typicality and greater preference for female friends would be related to more positive attitudes toward, greater success in, and higher persistence levels at the single-sex school (hypotheses 5a, 5b, 5c, $5 d, 5 e$, and 5f). Finally, we predicted that a sense of connection to the school would moderate the relation between endorsement of stereotypes and achievement (hypothesis 6a). See Table 1 for a summary of hypotheses.

\section{Method}

\section{Overview}

The current study is part of a large longitudinal study designed to investigate a broad range of outcomes associated with attending an all-girls public middle school located in a large city in the southwestern United States. The school's mission includes a focus on science, technology, math, and leadership. The first data collection occurred in the summer of 2007, prior to students' enrollment in the single-sex school. At this time, students completed measures of gender stereotyping and gender typicality (among other measures). A second data collection took place in late 2007, after students had been attending the single-sex school for approximately four months. At this time, students completed measures of the gender composition of their friends and school climate (among other measures). Data on students' grades was collected at the end of the first academic year. Data on persistence was collected at the end of the second academic year. 
Patterson, M. M., \& Pahlke, E. (2011). Student Characteristics Associated With Girls' Success in a Single-Sex School. Sex Roles, 65, 737-750. Publisher's official version: http://dx.doi.org/10.1007/s11199-010-9904-1. Open Access version: http://kuscholarworks.ku.edu/dspace/.

\section{Participants}

Participants were 211 students (116 sixth graders and 95 seventh graders, ages 10 to 13 at the first data collection, $M=11$ years 8 months, $S D=7.57$ months). The sample was $17.1 \%$ African American, 2.8\% Asian American, 28.0\% European American, and 52.1\% Latina. All participants had parental consent to complete surveys. Because surveys were administered at multiple time points, not all participating students completed all measures. Thus, analyses contain varying numbers of participants. For most measures, the number of non-participating students was quite low (less than $5 \%$ of the sample).

\section{Demographics}

Family income status. School district records of free or reduced-priced lunch eligibility served as the measure of family income. Students from families with incomes at or below 130\% of the national poverty level are eligible for free lunches, while students from families with incomes between 130 and 185\% of the poverty level are eligible for reduced-price lunches. Participants were coded as eligible for free lunch (38.4\%), eligible for reduced-price lunch (14.7\%), or ineligible for free or reduced-price lunch (46.9\%).

Race/ethnicity. Students’ racial/ethnic background was drawn from school district records. Two dummy coded race variables were created for use in analyses: African American and Latina (see Cohen, Cohen, West, \& Aiken, 2002). For both dummy coded variables, a combination of European American and Asian American students served as the reference group.

\section{Prior Academic Achievement}

Scores from state standardized tests of reading and math were obtained for each participant from the year prior to enrolling in the single-sex school (i.e., fifth grade scores for entering sixth graders and sixth grade scores for entering seventh graders) and served as a 
Patterson, M. M., \& Pahlke, E. (2011). Student Characteristics Associated With Girls' Success in a Single-Sex School. Sex Roles, 65, 737-750. Publisher's official version: http://dx.doi.org/10.1007/s11199-010-9904-1.

Open Access version: http://kuscholarworks.ku.edu/dspace/.

measure of prior academic achievement. Because these scores are not comparable across school years, we created z-scores based on the scores from the students' grade level (i.e., separately for scores from fifth grade and sixth grade students). Given that children's preparedness in math and reading can have distinct effects on later achievement (Duncan et al., 2007), we included prior math and reading achievement as separate scores.

\section{Gender Typicality}

Participants completed a measure of gender typicality (Patterson, 2008) that assessed perceived similarity to other girls in various domains (e.g., dress, speech, activity preferences). Participants were asked to rate the veracity of ten statements (e.g., "I like to do the same kinds of things as most girls”). Response options were really true (4), sort of true (3), sort of not true (2), and really not true (1). Scores for the ten items were averaged to create a composite gender typicality score; Cronbach’s $\alpha$ for this measure was .82 (see Table 2 for means and standard deviations).

\section{Gender-Typed Friend Preferences}

Gender composition of friends. Students were asked to report how many of their neighborhood friends were boys, using response options that ranged from none or hardly any (1) to almost all or all (4).

Interest in female friends. Students were asked to rate the extent to which they decided to attend an all-girls school because they wanted to become friends with more girls (i.e., "I would rather go to a school for girls because girls are better friends" and "I would rather go to a school for girls because I want to meet and make friends with other girls my age”; $r=.31, \mathrm{p}<$ .001). Response options ranged from very untrue (1) to very true (4).

\section{Stereotyping}


Patterson, M. M., \& Pahlke, E. (2011). Student Characteristics Associated With Girls' Success in a Single-Sex School. Sex Roles, 65, 737-750. Publisher's official version: http://dx.doi.org/10.1007/s11199-010-9904-1. Open Access version: http://kuscholarworks.ku.edu/dspace/.

Gender stereotyping of activities. Participants completed the activities subscale of the Occupations, Activities, and Traits - Attitudes Measure (OAT-AM; Liben \& Bigler, 2002). Participants rated whether only men, mostly men and some women, both men and women, mostly women and some men, or only women should perform a series of masculine, feminine, and gender-neutral activities (e.g., “who should fix bicycles?,” “who should knit a sweater?”). The proportion of gender stereotypic responses (i.e., agreement that activities should be completed by only or mostly members of one gender) was calculated, and thus higher scores indicate more stereotyped views. Cronbach’s $\alpha$ for this measure was .90.

Gender stereotyping of school-focused domains. Science- and leadership-related gender stereotyping was measured using a modified version of the stereotyping subscales of the Fennema-Sherman Attitudes Scale (e.g., "I would have more faith in a science problem solved by a man than by a woman," “Males are naturally better than females at leadership”; Doepken, Lawsky, \& Padwa, 1993). Response options ranged from strongly agree (5) to strongly disagree (1). Items from the science and leadership scales were averaged to create a single measure of students’ gender stereotyping in school-focused domains. Cronbach's $\alpha$ for the combined scale was .89.

\section{Outcomes}

School connection. Perceptions of connection to the school were assessed using the connection/climate subscale of the SRS Safe Schools Survey (Skiba et al., 2004). Students rated the degree to which they perceived their school as caring and fair and had a sense of belonging at school (e.g., "I feel welcome at this school”). Response options ranged from strongly agree (5) to strongly disagree (1). Scores for each item were averaged to create a composite school connection score; Cronbach’s $\alpha$ for this measure was .90 . 
Patterson, M. M., \& Pahlke, E. (2011). Student Characteristics Associated With Girls' Success in a Single-Sex School. Sex Roles, 65, 737-750. Publisher's official version: http://dx.doi.org/10.1007/s11199-010-9904-1. Open Access version: http://kuscholarworks.ku.edu/dspace/.

Academic performance. Students’ grades from their English, math, science, and social studies courses during their first year at the single-sex school were obtained from official district transcripts. Grades from the four core classes were averaged to create an overall grade point average.

Persistence. Using district records, we determined whether, after the second year in the school, each student had either (1) remained in the single-sex school, (2) left the school for a coeducational public school in the district, or (3) moved out of the district.

\section{Results}

\section{Overview}

Our primary goal was to identify student characteristics associated with students’ success in and connection to an all-girls educational environment. To do so, we examined three broad outcomes: (1) connection to the single-sex school, (2) academic performance at the single-sex school, and (3) persistence in the single-sex school. Correlations among these measures indicated that students' connection to the school at six months was significantly related to their academic performance after one year and their persistence in the school after two years (see Table 3). Persistence and academic performance were, however, unrelated and thus we chose to examine each outcome with separate regression models.

For each outcome, we first examined the predictive role of demographics and prior academic achievement. We then ran two sets of models that focused on issues related to gender; the first set of models focused on gender stereotyping variables, whereas the second set of models focused on gender identity variables. We chose to run separate models for gender identity and gender stereotyping variables because endorsement of stereotypes in science and leadership and perceptions of gender typicality were significantly related in the current sample ( $r$ 
Patterson, M. M., \& Pahlke, E. (2011). Student Characteristics Associated With Girls' Success in a Single-Sex School. Sex Roles, 65, 737-750. Publisher's official version: http://dx.doi.org/10.1007/s11199-010-9904-1.

Open Access version: http://kuscholarworks.ku.edu/dspace/.

$=-.17$; see Table 3 ) and because the relations between gender typicality and gender stereotyping are not well established in the existing literature (see Leaper \& Van, 2008 and Patterson, 2008 for some recent examinations). As part of each regression model we tested for issues of multicollinearity. The variance inflation factor (VIF) never exceeded 2, suggesting that multicollinearity was not a concern (Myers, 1990).

\section{Descriptive Statistics for Predictor Variables}

Gender identity. Students generally perceived themselves to be moderately gender typical (see Table 2 for means and standard deviations for all variables). Participants on average reported having "a few" male friends in their neighborhoods and interest in female friends was generally high (see Table 2).

Gender stereotyping. Participants were somewhat likely to endorse stereotypes about who should engage in particular activities. Students were generally low in endorsement of gender stereotypes related to science and leadership (see Table 2).

\section{Predictors of School Connection}

After spending a semester in the all-girls school, most students reported moderate feelings of connection to the school (see Table 2). To investigate the factors associated with girls' school connection, we ran a series of three linear regression models (see Table 1 for hypotheses). The first baseline model examined demographics and prior academic achievement. In this model, we regressed students' perception of school climate on family income status, race/ethnicity, prior math scores, and prior reading scores. Although we had not predicted racial differences in school connection, results indicated that identifying as African American (as opposed to Asian American or European American) was negatively associated with school connection (see Table 4). The second model focused on gender stereotyping variables. Results 
Patterson, M. M., \& Pahlke, E. (2011). Student Characteristics Associated With Girls' Success in a Single-Sex School. Sex Roles, 65, 737-750. Publisher's official version: http://dx.doi.org/10.1007/s11199-010-9904-1. Open Access version: http://kuscholarworks.ku.edu/dspace/.

indicated a significant $R^{2}$ change from the baseline model (demographics and prior achievement) to the gender stereotyping model (demographics, prior achievement, and gender stereotyping), $F(2,110)=3.94, p=.02$ (see Table 4). Endorsement of gender stereotypes of science and leadership (but not activities) significantly predicted school connection; girls who were lower in stereotype endorsement reported higher school connection than girls who were higher in stereotype endorsement.

The final model focused on gender identity variables. Results indicated no significant $R^{2}$ change from the baseline model (demographics and prior achievement) to the gender identity model (demographics, prior achievement, and gender identity), $F(3,91)=2.47, p=.07$ (see Table 4). The percentage of male friends students reported having was negatively related to school connection at the all-girls school. However, because the model including gender identity variables did not have significantly improved predictive power beyond that of the baseline model, this finding should be interpreted with caution.

\section{Predictors of Academic Performance}

To investigate the factors associated with girls’ academic performance in a single-sex environment, we ran a series of linear regression models (see Table 1 for hypotheses). In the first baseline model, we examined demographics and prior academic achievement. Consistent with our hypotheses, family income status and the race/ethnicity dummy coded variables were all significant predictors; students’ grades rose as their family income level increased, and African American and Latina students showed poorer performance than Asian American and European American students (see Table 5). Prior math achievement (but not prior reading achievement) significantly predicted academic performance; girls with higher math achievement scores at 
Patterson, M. M., \& Pahlke, E. (2011). Student Characteristics Associated With Girls' Success in a Single-Sex School. Sex Roles, 65, 737-750. Publisher's official version: http://dx.doi.org/10.1007/s11199-010-9904-1.

Open Access version: http://kuscholarworks.ku.edu/dspace/.

entry had higher grades in the first year of attendance at the single-sex school than girls with lower math scores at entry.

The second model focused on gender stereotyping variables. Results indicated a significant $R^{2}$ change from the baseline model (demographics and prior achievement) to the gender stereotyping model (demographics, prior achievement, and gender stereotyping), $F(2$, 123) $=9.37, p<.001$ (see Table 5). Race, family income status, and prior math achievement continued to be significant predictors of academic performance. Results also indicated a significant effect of endorsement of gender stereotypes in science and leadership (but not endorsement of gender stereotypes of activities); consistent with our hypothesis, girls who were lower in science and leadership stereotype endorsement had higher grades than students with higher stereotype endorsement.

The final model focused on gender identity variables. Results indicated no significant $R^{2}$ change from the baseline model (demographics and prior achievement) to the gender identity model (demographics, prior achievement, and gender identity), $F(3,89)=.43, p=.73$ (see Table 5). Including gender identity variables (gender typicality and friend preferences) in the model did not explain any additional variance in students' grades at the end of their first year at the single-sex school.

\section{Predictors of Persistence}

Of the 211 students in the entry cohort, 149 (71\%) were still enrolled in the school after two years. Of the 62 students who left the school, 12 (6\%) left because their families moved out of the district. The remaining 50 students (24\%) left the all-girls school and returned to a coeducational public school in the district. To investigate the factors that might contribute to girls’ persistence in a single-sex environment, we ran a series of binomial logistic regression 
Patterson, M. M., \& Pahlke, E. (2011). Student Characteristics Associated With Girls' Success in a Single-Sex School. Sex Roles, 65, 737-750. Publisher's official version: http://dx.doi.org/10.1007/s11199-010-9904-1.

Open Access version: http://kuscholarworks.ku.edu/dspace/.

models related to the decision to remain at the single-sex school after two years (see Table 1 for hypotheses). Persistence was the outcome variable (with persisting in the school coded as 1 and leaving the school for another school in the district coded as 0). Students who left the all-girls school because their families moved out of the district were not included in the analyses.

To investigate the factors associated with girls’ persistence at the single-sex school, we ran a series of linear regression models. In the first baseline model we examined demographics and prior academic achievement. In this model, we regressed students’ persistence on family income status, race/ethnicity, prior math scores, and prior reading scores. Neither family income status nor race/ethnicity (i.e., identifying as African American or Latina) significantly predicted persistence in the single-sex school. Our hypothesis regarding prior academic achievement was not supported; prior reading achievement (but not prior math achievement) was a significant predictor of persistence in the single-sex school; students with higher prior reading achievement were less likely to remain in the single-sex school after two years than students with lower prior reading achievement (see Table 6). Although prior reading achievement significantly predicted persistence, the model explained very little of the variation in persistence (Cox \& Snell $R^{2}=.08$ ). As such, in the next two models we focused on the potential explanatory power of gender stereotyping and gender identity.

The second model focused on gender stereotyping variables (see Table 6). Prior reading achievement continued to be a significant predictor of persistence. Neither of the gender stereotyping variables, however, significantly predicted the odds of persistence in the single-sex school.

The third model focused on gender identity variables (see Table 6). Results indicated a substantial $R^{2}$ change from the baseline model (demographics and prior achievement) to the 
Patterson, M. M., \& Pahlke, E. (2011). Student Characteristics Associated With Girls' Success in a Single-Sex School. Sex Roles, 65, 737-750. Publisher's official version: http://dx.doi.org/10.1007/s11199-010-9904-1. Open Access version: http://kuscholarworks.ku.edu/dspace/.

gender identity model (demographics, prior achievement, and gender identity). Prior reading achievement continued to be a significant predictor of persistence. Consistent with our hypotheses, results also indicated significant effects of both friendship variables; students who reported a higher number of male friends at entry were less likely to persist in the single-sex school than students with fewer male friends, whereas girls who reported a stronger preference for female friends at entry were more likely to persist in the single-sex school than students with less of a preference for female friends. Gender typicality was not, however, a significant predictor of persistence.

\section{School Connection as a Moderator}

Given the observed relations between (a) school connection and academic performance (see Table 3), (b) gender stereotyping of science and leadership and school connection (see Table 4), and (c) gender stereotyping of science and leadership and academic performance (see Table 5), we predicted that students' perceptions of connection to the school would moderate the relation between gender stereotyping and academic performance at the single-sex school. In order to test this hypothesis, we ran a hierarchical linear regression model that included the same demographic and prior academic achievement variables included in previous models, along with gender stereotyping of science and leadership, school connection, and an interaction term between stereotyping and school connection. All of the terms involved with the interaction were calculated based on mean centered values (Aiken \& West, 1991).

The overall model explained almost $50 \%$ of the variation in GPA $\left(R^{2}=.49, p<.001\right)$. As in the previous academic performance model (see Table 5), endorsement of gender stereotypes in the school-focused domains of science and leadership was a significant predictor of GPA in the single-sex school $(\beta=-.22, p=.002)$. School connection, on the other hand, did not significantly 
Patterson, M. M., \& Pahlke, E. (2011). Student Characteristics Associated With Girls' Success in a Single-Sex School. Sex Roles, 65, 737-750. Publisher's official version: http://dx.doi.org/10.1007/s11199-010-9904-1.

Open Access version: http://kuscholarworks.ku.edu/dspace/.

predict GPA $(\beta=.07, p=.30)$ in this model. The interaction term was statistically significant, however $(\beta=.16, p=.01)$. Figure 1 plots the interaction and shows the simple slopes for the relation between endorsement of gender stereotypes and GPA at three values of connection to school: one standard deviation below the mean, the mean, and one standard deviation above the mean. Tests of the simple slopes indicated that the relation between endorsement of gender stereotypes and GPA was significant at all three levels of connection to school. However, Figure 1 indicates that the relation between gender stereotyping and GPA differs depending on the student's level of school connection. For all students, gender stereotype endorsement was negatively related to GPA, but the relation between stereotype endorsement and GPA was stronger for students high in school connection and weaker for students low in school connection.

\section{Discussion}

The current study aimed to identify group (e.g., race) and individual (e.g., gender identity) differences that are related to students' success in and connection to an all-girls educational environment. We examined the associations between demographic variables, prior academic achievement, gender stereotyping, and gender identity and three outcome variables: connection to the single-sex school, academic performance, and persistence.

Our data indicated that African American and Latina students tended to have lower grades than other students, and that this relation held even after accounting for family income status and prior academic achievement. That is, the race-related achievement gaps seen in the U.S. at large (Planty et al., 2009) were also seen in the target school. However, the current study included only one year of data; future long-term longitudinal research should examine whether minority and low-income students show greater gains over time in single-sex educational 
Patterson, M. M., \& Pahlke, E. (2011). Student Characteristics Associated With Girls' Success in a Single-Sex School. Sex Roles, 65, 737-750. Publisher's official version: http://dx.doi.org/10.1007/s11199-010-9904-1.

Open Access version: http://kuscholarworks.ku.edu/dspace/.

environments than other students, as posited by some advocates for single-sex schooling (e.g., Ascher, 1992; Riordan, 1994, 2002; Salomone, 2002).

African American students felt less connected to the single-sex school than their peers. This finding may be partially explained by African American students’ numeric minority status within this particular all-girls school. Previous research (e.g., Graham \& Juvonen, 2002) suggests that students' school experiences are influenced by their racial or ethnic groups’ numeric presence within the school context. So, in this case, African Americans (but not Latinas) may have felt less connected because of a combination of their minority status in the school context and their minority status within the broader society. Future work that attempts to draw conclusions about the effectiveness of single-sex schooling for racial/ethnic groups should consider the groups' numeric majority or minority status within both the school and the broader society. Another possible explanation is that the relative importance of gender identity may vary based on ethnicity (Corby, Hodges, \& Perry, 2007; Turner \& Brown, 2007). The African American girls in this sample may have placed less emphasis on gender than other students, and thus felt less of a connection to the other students at the school based on their shared gender.

Prior achievement was a significant predictor of academic achievement and persistence, although the relevant aspect of prior achievement varied. Prior math achievement predicted later grades, whereas prior reading achievement predicted persistence. Students with higher math test scores (but not higher reading scores) received higher grades in their first year at the single-sex school, perhaps due to the school's emphasis on science, math, and technology domains. Students with higher reading achievement scores were less likely to persist at the single-sex school after two years than students with lower reading achievement scores. One possible explanation for this finding is that students who were highly skilled in reading may have disliked 
Patterson, M. M., \& Pahlke, E. (2011). Student Characteristics Associated With Girls' Success in a Single-Sex School. Sex Roles, 65, 737-750. Publisher's official version: http://dx.doi.org/10.1007/s11199-010-9904-1. Open Access version: http://kuscholarworks.ku.edu/dspace/.

the school's emphasis on science, math, and technology domains, and thus chosen to leave the school at higher rates. Future research should further examine the influence of academic achievement, including achievement at the target school, on students’ persistence at single-sex schools.

Gender stereotyping was also a significant predictor of both connection with and achievement at the all-girls school. Interestingly, stereotyping of science and leadership (academic domains emphasized at the school) was a significant predictor of grades and connection, but a more general measure of activity stereotyping was not a significant predictor for any of the outcome variables. Students who showed greater endorsement of gender stereotypes related to science and leadership had lower grades and lower school connection; students with more egalitarian views had higher grades and felt more connected to the school. This finding suggests that issues of "fit” between a student's attitudes and the focus or mission of a particular school may be an important issue relating to the impact of stereotype endorsement on achievement. This finding also indicates that general measures of gender stereotyping may be inadequate to detect influences of stereotypes in a particular context; context-specific stereotyping measures may have greater validity.

Future research is needed to better understand the process by which endorsement of gender stereotypes influences academic achievement and school connection, particularly within the context of single-sex schools. It is important to note that these data indicate an impact of gender stereotyping on students’ grades even after controlling for prior academic achievement. This indicates that there may be an influence of students' gender-role beliefs on their behaviors in relevant academic domains, rather than simply a projection effect in which girls with interest or ability in these domains are lower in stereotype endorsement. The influence of gender-role 
Patterson, M. M., \& Pahlke, E. (2011). Student Characteristics Associated With Girls' Success in a Single-Sex School. Sex Roles, 65, 737-750. Publisher's official version: http://dx.doi.org/10.1007/s11199-010-9904-1.

Open Access version: http://kuscholarworks.ku.edu/dspace/.

beliefs on individual behaviors may be especially strong for students high in gender schematicity (Liben \& Bigler, 2002) or in environments that make gender highly salient. Thus, single-sex schools may have positive impacts on academic achievement to the extent that they reduce gender stereotyping of academic domains among students who attend them.

In addition to gender stereotyping, this research examined the association of gender identity variables with school-related outcomes. Gender typicality was not a significant predictor of any of the three outcome variables, indicating that whether a student perceived herself to be high or low in gender typicality had no bearing on grades, connection, or persistence in a single-sex educational environment. This finding differs from earlier studies on the importance of gender typicality in single-sex environments (Drury et al., 2009). There are a number of possible explanations for this finding. First, previous studies on outcomes associated with gender typicality (e.g., Drury et al., 2009; Smith \& Leaper, 2005) primarily examined outcomes related to peer relationships, whereas the current study focused on academic outcomes. Also, the current study included an assessment of gender typicality at only one time point (prior to entry into the single-sex school). Given that individuals may base their perceptions of their own gender typicality on a wide range of characteristics (Egan \& Perry, 2001), participants’ selfperceived gender typicality may have changed over time. It is possible, in fact, that the singlesex environment itself may have influenced students' perceptions of what is gender-typical behavior and thus influenced their self-perceived gender typicality and related outcomes. Future research should examine the possible ways in which single-sex environments may influence perceptions of gender typicality.

Desire for male versus female friends did have an effect on students’ persistence at the single-sex school, however. Unsurprisingly, girls who had fewer male friends and a greater 
Patterson, M. M., \& Pahlke, E. (2011). Student Characteristics Associated With Girls' Success in a Single-Sex School. Sex Roles, 65, 737-750. Publisher's official version: http://dx.doi.org/10.1007/s11199-010-9904-1. Open Access version: http://kuscholarworks.ku.edu/dspace/.

interest in female friends were more likely to remain at the single-sex school than girls who had more male friends or less interest in female friends. This could simply be due to social motivations to attend a school with the largest number of potential friends of a desired type. It is also possible, however, that students who had fewer male friends or expressed a greater desire for female friends did so out of out of a general sense of ingroup gender bias (Powlishta, 1995, 2004). This bias in favor of the gender ingroup may have encouraged girls to remain at the single-sex school above and beyond their desire for female friends. That is, girls who had a stronger ingroup preference or bias may have been more likely to remain in the single-sex school than girls with lower levels of ingroup bias. Future research should examine the influence of multiple aspects of bias on students’ preference for single-sex educational environments.

Finally, this study examined the possible role of school connection as a moderator of the observed relation between gender stereotyping and academic performance at a single-sex school. We found that, although gender stereotype endorsement was negatively related to GPA for all students, school connection interacted with stereotyping in predicting student grades. This finding indicates that high levels of connection to the single-sex school are not a protective factor against the negative impact of gender stereotypes. In fact, more connected students were more strongly impacted by gender stereotyping than less connected students. That is, students who were more strongly identified with the school and who held stereotyped beliefs about the academic domains emphasized at the school may have been more negatively impacted by their stereotypical beliefs than students who were less strongly identified with the school. This finding parallels other research on the importance of domain identification on performance, such as findings from the stereotype threat literature indicating that individuals who are strongly 
Patterson, M. M., \& Pahlke, E. (2011). Student Characteristics Associated With Girls' Success in a Single-Sex School. Sex Roles, 65, 737-750. Publisher's official version: http://dx.doi.org/10.1007/s11199-010-9904-1.

Open Access version: http://kuscholarworks.ku.edu/dspace/.

identified with a particular domain show greater effects of stereotype threat on performance than individuals who are not identified with the domain (Aronson et al., 1999; Steele, 1997).

This study is one of the first to examine whether individual difference variables are useful for predicting students' success within single-sex schools and thus makes a novel contribution to the literature on single-sex schooling. However, it is a study of one specific school and thus findings may not generalize to other populations. Future research should examine the extent to which these findings apply to other groups of students attending single-sex schools, including boys and students of other ages. Given the existence of research on the influence of cultural context on the efficacy of single-sex schools (Baker et al., 1995), future research should also examine the extent to which the observed relations occur in settings outside of the U.S., particularly in non-Western countries. In addition, future studies should follow students over longer periods of time in order to allow for the longitudinal exploration of additional individual and school factors. For example, future studies should examine academic performance at multiple time points to examine whether students with different characteristics obtain differing levels of benefit from the single-sex educational environment. Future research should also further explore the interrelations among stereotype endorsement, school connection, and academic achievement observed in the present study. Despite the need for future work, the current study does provide important information about the factors that may influence student success in single-sex schools. Educators, policy makers, and researchers debating the efficacy of single-sex schools should consider the individual factors that may lead certain students to thrive in single-sex educational environments. 
Patterson, M. M., \& Pahlke, E. (2011). Student Characteristics Associated With Girls' Success in a Single-Sex School. Sex Roles, 65, 737-750. Publisher's official version: http://dx.doi.org/10.1007/s11199-010-9904-1.

Open Access version: http://kuscholarworks.ku.edu/dspace/.

\section{References}

Aiken, L. S., \& West, S. G. (1991). Multiple regression: Testing and interpreting interactions. Newbury Park, CA: Sage.

American Association of University Women. (1998). Separated by Sex: A Critical Look at SingleSex Education for Girls. Washington, DC: The American Association of University Women Foundation.

Aronson, J., Lustina, M. J., Good, C., Keough, K., Steele, C. M., \& Brown, J. (1999). When White men can't do math: Necessary and sufficient factors in stereotype threat. Journal of Experimental Social Psychology, 35, 29-46. doi:10.1006/jesp.1998.1371

Arthur, A. E., Bigler, R. S., Liben, L. S., Gelman, S. A., \& Ruble, D. N. (2008). Gender stereotyping and prejudice in young children: A developmental intergroup perspective. In S.R. Levy \& M. Killen (Eds.) Intergroup Attitudes and Relations in Childhood through Adulthood. (pp. 6686) New York: Oxford.

Ascher, C. (1992). School programs for African-American males... and females. Phi Delta Kappan, 73, 777-782.

Australian Bureau of Statistics. (1997). Australian Social Trends, 1997. Retrieved from http://www.abs.gov.au/AUSSTATS/abs@.nsf/2f762f95845417aeca25706c00834efa/80fbc48 26c05c115ca2570ec001b193c!OpenDocument.

Baker, D. P., Riordan, C., \& Schaub, M. (1995). The effects of sex-grouped schooling on achievement: The role of national context. Comparative Education Review, 39, 468-482. $\underline{\text { doi:10.1086/447341 }}$

Baki, R. (2004). Gender-segregated education in Saudi Arabia: Its impact on social norms and the Saudi labor market. Education Policy Analysis Archives, 12(28). 
Patterson, M. M., \& Pahlke, E. (2011). Student Characteristics Associated With Girls' Success in a Single-Sex School. Sex Roles, 65, 737-750. Publisher's official version: http://dx.doi.org/10.1007/s11199-010-9904-1.

Open Access version: http://kuscholarworks.ku.edu/dspace/.

Barnett, R., \& Rivers, C. (2004). Same difference: How gender myths are hurting our relationships, our children, and our jobs. New York: Basic Books.

Bigler, R. S., \& Liben, L. S. (2006). A developmental intergroup theory of social stereotypes and prejudice. In R. Kail (Ed.) Advances in Child Development and Behavior (Vol. 34, pp. 3989). San Diego: Elsevier.

Boswell, S. L. (1985). The influence of sex-role stereotyping on women's attitudes and achievement in mathematics. In S. F. Chipman, L. R. Brush, \& D. M. Wilson (Eds.) Women and Mathematics: Balancing the Equation (pp. 175-197). Hillsdale, NJ: Lawrence Erlbaum.

Bracey, G. W. (2006). Separate but Superior? A Review of Issues and Data Bearing on Single-Sex Education. Retrieved from http://www.greatlakescenter.org/docs/Policy_Briefs/Bracey_Gender.pdf.

Cairns, E. (1990). The relationship between adolescent perceived self-competence and attendance at single-sex secondary school. British Journal of Educational Psychology, 60, 207-211.

Campbell, P. B., \& Sanders, J. (2002). Challenging the system: Assumptions and data behind the push for single-sex schooling. In A. Datnow and L. Hubbard (Eds.), Gender in policy and practice: Perspectives on single-sex and coeducational schooling (pp. 31-46). New York: RoutledgeFalmer.

Caplice, K. S. (1994). The case for public single-sex education. Harvard Journal of Law \& Public Policy, 18, 227-292.

Cohen, J., Cohen, P., West, S. G., Aiken, L. S. (2002). Applied multiple regression - correlation analysis for the behavioral sciences (3rd ed.). Mahwah, NJ: Lawrence Erlbaum.

Corby, B. C., Hodges, E. V. E., \& Perry, D. G. (2007). Gender identity and adjustment in Black, Hispanic, and White preadolescents. Developmental Psychology, 43, 261-266. $\underline{\text { doi:10.1037/0012-1649.43.1.261 }}$ 
Patterson, M. M., \& Pahlke, E. (2011). Student Characteristics Associated With Girls' Success in a Single-Sex School. Sex Roles, 65, 737-750. Publisher's official version: http://dx.doi.org/10.1007/s11199-010-9904-1.

Open Access version: http://kuscholarworks.ku.edu/dspace/.

Datnow, A., Hubbard, L., \& Woody, E. (2001). Is Single Gender Schooling Viable in the Public Sector? Lessons from California’s Pilot Program. Retrieved from http://eric.ed.gov/ ERICDocs/data/ericdocs2sql/content_storage_01/0000019b/80/1a/98/46.pdf.

Doepken, D., Lawsky, E., \& Padwa, L. (1993). Modified Fennema-Sherman attitude scales. Retrieved from http://www.woodrow.org/teachers/math/gender/08scale.html.

Drury, K.-M., Bukowski, W. M., Saldarriaga, L.M., \& Santo, J. B. (2009, April). Gender Typicality Across Social Contexts. Poster presented at the biennial meeting of the Society for Research in Child Development, Denver, CO.

Duncan, G. J., Dowsett, C. J., Claessens, A., Magnuson, K., Huston, A. C., Klebanov, P., et al. (2007). School readiness and later achievement. Developmental Psychology, 43, 1428-1446. $\underline{\text { doi:10.1037/0012-1649.43.6.1428 }}$

Egan, S. K., \& Perry, D. G. (2001). Gender identity: A multidimensional analysis with implications for psychosocial adjustment. Developmental Psychology, 37, 451-463. doi:10.1037/0012$\underline{1649.37 .4 .451}$

Fennema, E., \& Sherman, J. A. (1977). Sex-related differences in mathematics achievement, spatial visulization and sociocultural factors. American Educational Research Journal, 14, 51- 71.

Fennema, E., \& Sherman, J. A. (1978). Sex-related differences in mathematics achievement and other factors: A further study. Journal for Research in Mathematics Education, 9, 189-203. $\underline{\text { doi:10.2307/748997 }}$

Furrer, C., \& Skinner, E. (2003). Sense of relatedness as a factor in children's academic engagement and performance. Journal of Educational Psychology, 95, 148-162. doi:10.1037/0022$\underline{0663.95 .1 .148}$ 
Patterson, M. M., \& Pahlke, E. (2011). Student Characteristics Associated With Girls' Success in a Single-Sex School. Sex Roles, 65, 737-750. Publisher's official version: http://dx.doi.org/10.1007/s11199-010-9904-1.

Open Access version: http://kuscholarworks.ku.edu/dspace/.

Galambos, N. L., Almeida, D. M., \& Petersen, A. C. (1990). Masculinity, femininity, and sex role attitudes in early adolescence: Exploring gender intensification. Child Development, 61, 1905-1914. doi:10.2307/1130846

Gewertz, E. (2007, June 20). Black boys' educational plight spurs single-gender schools; New federal rules seen as chance for innovation. Education Week, 26(42), 1-25.

Graham, S., \& Juvonen, J. (2002). Ethnicity, peer harassment, and adjustment in middle school: An exploratory study. Journal of Early Adolescence, 22, 173-199. doi:10.1177/0272431602022002003

Gurian, M. (2001). Boys and girls learn differently! San Francisco: Jossey-Bass.

Gwizdala, J., \& Steinback, M. (1990). High school females' mathematics attitudes: An interim report. School Science and Mathematics, 90, 215-222. doi:10.1111/j.1949-8594.1990.tb15537.x

Hansen, J. M., \& Childs, J. (1998). Creating a school where people like to be. Educational Leadership, 56, 14-17.

Harris, M. B. (1986). Coeducation and sex roles. Australian Journal of Education, 30, 117-131.

Hoffman, M. L., \& Powlishta, K. K. (2001). Gender segregation in childhood: A test of the interaction style theory. Journal of Genetic Psychology, 162, 298-313. doi:10.1080/00221320109597485

Huston, A. C., \& Alvarez, M. M. (1990). The socialization context of gender role development in early adolescence. In R. Montemayor, G. R. Adams, \& T. P. Gullotta (Eds.), From childhood to adolescence: A transitional period? (pp. 156-179). Newbury Park, CA: Sage.

Jayaratne, T. E., Thomas, N. G., \& Trautman, M. (2003). Intervention program to keep girls in the science pipeline: Outcome differences by ethnic status. Journal of Research in Science Teaching, 40, 393-414. doi:10.1002/tea.10082 
Patterson, M. M., \& Pahlke, E. (2011). Student Characteristics Associated With Girls' Success in a Single-Sex School. Sex Roles, 65, 737-750. Publisher's official version: http://dx.doi.org/10.1007/s11199-010-9904-1.

Open Access version: http://kuscholarworks.ku.edu/dspace/.

Jimenez, E., \& Lockheed, M. E. (1989). Enhancing girls' learning through single-sex education: Evidence and a policy conundrum. Educational Evaluation and Policy Analysis, 11, 117-142.

Leaper, C., \& Van, S. R. (2008). Masculinity ideology, covert sexism, and perceived gender typicality in relation to young men's academic motivation and choices in college. Psychology of Men and Masculinity, 9, 139-153. doi:10.1037/1524-9220.9.3.139

Lee, V. E. (1998). Is single-sex secondary schooling a solution to the problem of gender inequity? In S. Morse (Ed.), Separated by sex: A critical look at single-sex education for girls (pp. 41-53). Washington, DC: AAUW Educational Foundation.

Lee, V. E., \& Bryk, A. S. (1986). Effects of single-sex secondary schools on student achievement and attitudes. Journal of Educational Psychology, 78, 381-395. doi:10.1037/0022$\underline{0663.78 .5 .381}$

Lee, V. E., \& Bryk, A. S. (1989). Effects of single-sex schools: Reply to Marsh. Journal of Educational Psychology, 81, 647-650. doi:10.1037/0022-0663.81.4.647

Lee, V. E., \& Lockheed, M. E. (1990). The effect of single-sex schooling and attitudes in Nigeria. Comparative Education Review, 34, 209-231. doi:10.1086/446918

Lee, V. E., \& Marks, H. M. (1990). Sustained effects of the single-sex secondary school experience on attitudes, behaviors, and values in college. Journal of Educational Psychology, 82, 578592. doi:10.1037/0022-0663.82.3.578

Lee, V. E., Marks, H. M., \& Byrd, T. (1994). Sexism in single-sex and coeducational independent secondary school classrooms. Sociology of Education, 67, 92-120. doi:10.2307/2112699

Le Pore, P. C., \& Warren, J. R., (1997). A comparison of single-sex and coeducational Catholic secondary schooling: Evidence from the National Educational Longitudinal Study of 1988. American Educational Research Journal, 34, 485-511. 
Patterson, M. M., \& Pahlke, E. (2011). Student Characteristics Associated With Girls' Success in a Single-Sex School. Sex Roles, 65, 737-750. Publisher's official version: http://dx.doi.org/10.1007/s11199-010-9904-1.

Open Access version: http://kuscholarworks.ku.edu/dspace/.

Liben, L. S., \& Bigler, R. S. (2002). The developmental course of gender differentiation:

Conceptualizing, measuring, and evaluating constructs and pathways. Monographs of the Society for Research in Child Development, 67(Serial No. 269). doi: 10.1111/1540-

5834.t01-1-00187

Mael, F. A. (1998). Single-sex and coeducational schooling: Relationships to socioemotional and academic development. Review of Educational Research, 68, 101-129.

Maccoby, E. E. (1998). The two sexes: Growing up apart, coming together. Cambridge, MA: Harvard University Press.

Maccoby, E.E., \& Jacklin, C.N. (1987). Gender segregation in childhood. In E.H. Reese (Ed.) Advances in Child Development and Behavior (vol. 20, pp. 195-216). New York: Academic Press.

Martin, C.L., \& Fabes, R.A. (2001). The stability and consequences of young children’s same-sex peer interactions. Developmental Psychology, 37, 431-446. doi:10.1037/0012$\underline{1649.37 .3 .431}$

Martin, C. L., \& Ruble, D. N. (2010). Patterns of gender development. Annual Review of Psychology, 61, 353-381. doi:10.1146/annurev.psych.093008.100511

Myers, R. (1990). Classical and modern regression with applications ( $2^{\text {nd }}$ ed.). Boston: Duxbury Press.

National Association for Single Sex Public Education. (2010). Retrieved from http://www.singlesexschools.org.

Oakes, J. (1990). Opportunities, achievement, and choice: Women and minority students in science and mathematics. Review of Research in Education, 16, 153-222.

Osterman, K. F. (2000). Students' need for belonging in the school community. Review of Educational Research, 70, 323-367. 
Patterson, M. M., \& Pahlke, E. (2011). Student Characteristics Associated With Girls' Success in a Single-Sex School. Sex Roles, 65, 737-750. Publisher's official version: http://dx.doi.org/10.1007/s11199-010-9904-1.

Open Access version: http://kuscholarworks.ku.edu/dspace/.

Patterson, M. M. (2008, April). A new measure of self-perceived gender typicality. Poster presented at the biennial Gender Development Research Conference, San Francisco, CA.

Patterson, M. M., \& Bigler, R. S. (2007). Relations among social identities, intergroup attitudes, and schooling: Perspectives from intergroup theory and research. In A. Fuligni (Ed.), Contesting stereotypes and creating identities: Social categories, social identities and educational participation (pp. 66-87). New York: Russell Sage.

Planty, M., Hussar, W., Snyder, T., Kena, G., KewalRamani, A., Kemp, J., Bianco, K., \& Dinkes, R. (2009). The condition of education 2009 (NCES 2009-081). National Center for Education Statistics, Institute of Education Sciences, U.S. Department of Education. Washington, DC.

Powlishta, K. K. (1995). Intergroup processes in childhood: Social categorization and sex role development. Developmental Psychology, 31, 781-788. doi:10.1037/0012-1649.31.5.781

Powlishta, K. K. (2004). Gender as a social category: Intergroup processes and gender-role development. In M. Bennett \& F. Sani (Eds.) The development of the social self. (pp. 103133). New York, NY, US: Psychology Press. doi:10.4324/9780203391099_chapter_4.

Riordan, C. (1990). Girls and Boys in School: Together or Separate? New York: Teachers College Press.

Riordan, C. (1994). Single-gender schools: Outcomes for African and Hispanic Americans. Research in Sociology of Education and Socialization, 10, 177-205.

Riordan, C. (2002). What do we know about the effects of single-sex schools in the private sector? Implications for public schools. In A. Datnow and L. Hubbard (Eds.), Gender in policy and practice: Perspectives on single-sex and coeducational schooling (pp. 10-30). New York: RoutledgeFalmer.

Ruble, D. N., Martin, C. L., \& Berenbaum, S. A. (2006). The development of gender-related constructs and content. In W. Damon \& R.M. Lerner (Series Eds.) \& N. Eisenberg (Volume 
Patterson, M. M., \& Pahlke, E. (2011). Student Characteristics Associated With Girls' Success in a Single-Sex School. Sex Roles, 65, 737-750. Publisher's official version: http://dx.doi.org/10.1007/s11199-010-9904-1.

Open Access version: http://kuscholarworks.ku.edu/dspace/.

Ed.) Handbook of Child Psychology: Vol. 3, Social, Emotional, and Personality Development (6th ed., pp. 858-932). New York: John Wiley \& Sons.

Salomone, R. C. (2002). Same, different, equal: Rethinking single-sex schooling. New Haven, Conn.: Yale University Press.

Salomone, R. C. (2006). Single-sex programs: Resolving the research conundrum. Teachers College Record, 108, 778-802. doi:10.1111/j.1467-9620.2006.00628.x

Sax, L. (2005). Why gender matters. New York: Doubleday.

Sherblom, S. A., Marshall, J. C., \& Sherblom, J. C. (2006). The relationship between school climate and math and reading achievement. Journal of Research in Character Education, 4, 19-31.

Shmurak, C. (1998). Voices of hope: Adolescent girls at single-sex and coeducational schools. New York: Peter Lang.

Signorella, M. L., Frieze, I. H., \& Hershey, S. W. (1996). Single-sex versus mixed-sex classes and gender schemata in children and adolescents. Psychology of Women Quarterly, 20, 599-607. doi:10.1111/j.1471-6402.1996.tb00325.x

Singh, K., Vaught, C., \& Mitchell, E. W. (1998). Single-sex classes and academic achievement in two inner-city schools. Journal of Negro Education, 67, 157-167. doi:10.2307/2668225

Skiba, R., Simmons, A. B., Peterson, R., McKelbey, J., Forde, S., \& Gallini, S. (2004). Beyond guns, drugs, and gangs: The structure of student perceptions of school safety. Journal of School Violence, 3, 149-171. doi:10.1300/J202v03n02_09

Smith, T. E. \& Leaper, C. (2005). Self-perceived gender typicality and the peer context during adolescence. Journal of Research on Adolescence, 16, 91-103. doi:10.1111/j.15327795.2006.00123.x

Steele, C. M. (1997). A threat in the air: How stereotypes shape intellectual identity and performance. American Psychologist, 52, 613-629. doi:10.1037/0003-066X.52.6.613 
Patterson, M. M., \& Pahlke, E. (2011). Student Characteristics Associated With Girls' Success in a Single-Sex School. Sex Roles, 65, 737-750. Publisher's official version: http://dx.doi.org/10.1007/s11199-010-9904-1.

Open Access version: http://kuscholarworks.ku.edu/dspace/.

Streitmatter, J. (1999). For Girls Only: Making a Case for Single-Sex Schooling. Albany, NY: SUNY Press.

Thompson, T., \& Ungerleider, C. (2004). Single Sex Schooling: Final Report. Toronto, Ontario, Canada: Council of Ministers of Education, Canada. Retrieved from http://www.cmec.ca/Publications/Lists/Publications/Attachments/61/singlegender.en.pdf.

Turner, K. L., \& Brown, C. S. (2007). The centrality of gender and ethnic identities across individuals and contexts. Social Development, 16, 700-719. doi:10.1111/j.1467$\underline{9507.2007 .00403 . x}$

U.S. Department of Education, Office of Planning, Evaluation and Policy Development, Policy and Program Studies Service. (2005). Single-Sex Versus Coeducational Secondary Schooling: A Systematic Review. Retrieved from http://www2.ed.gov/rschstat/eval/other/singlesex/index.html.

Wigfield, A., \& Eccles, J. (2000). Expectancy-value theory of achievement motivation. Contemporary Educational Psychology, 25, 68-81. doi:10.1006/ceps.1999.1015

Wood, B. S., \& Brown, L. A. (1997). Participation in an all-female algebra I class: Effects on high school math and science course selection. Journal of Women and Minorities in Science and Engineering, 3, 265-277. 
Patterson, M. M., \& Pahlke, E. (2011). Student Characteristics Associated With Girls' Success in a Single-Sex School. Sex Roles,

65, 737-750. Publisher's official version: http://dx.doi.org/10.1007/s11199-010-9904-1.

Open Access version: http://kuscholarworks.ku.edu/dspace/.

Table 1

Summary of Hypotheses and Results

\begin{tabular}{|c|c|c|}
\hline Domain & Hypothesis & Result \\
\hline Family income status & \#1a: Predicts academic performance & Supported \\
\hline \multirow[t]{3}{*}{ Race/ethnicity } & \#2a: Predicts academic performance (Asian & Supported \\
\hline & Americans and European Americans > & \\
\hline & African Americans and Latinas) & \\
\hline \multirow{3}{*}{$\begin{array}{l}\text { Prior academic } \\
\text { achievement in math }\end{array}$} & \#3a: Predicts school connection & Not supported \\
\hline & \#3b: Predicts academic performance & Supported \\
\hline & \#3c: Predicts persistence at the school & Not supported \\
\hline \multirow{3}{*}{$\begin{array}{l}\text { Gender stereotype } \\
\text { endorsement }\end{array}$} & \#4b: Negatively predicts academic & Supported \\
\hline & performance & \\
\hline & $\begin{array}{l}\text { \#4c: Negatively predicts persistence at the } \\
\text { school }\end{array}$ & Not supported \\
\hline \multirow[t]{3}{*}{ Gender typicality } & \#5a: Predicts school connection & Not supported \\
\hline & \#5b: Predicts academic performance & Not supported \\
\hline & \#5c: Predicts persistence at the school & Not supported \\
\hline \multirow{3}{*}{$\begin{array}{l}\text { Preferences for same- } \\
\text { gender friends }\end{array}$} & \#6a: Predicts school connection & Supported \\
\hline & \#6b: Predicts academic performance & Not supported \\
\hline & \#6c: Predicts persistence at the school & Supported \\
\hline School connection & $\begin{array}{l}\text { \#7a: Moderates relation between gender } \\
\text { stereotype endorsement and academic } \\
\text { performance }\end{array}$ & Supported \\
\hline
\end{tabular}


Patterson, M. M., \& Pahlke, E. (2011). Student Characteristics Associated With Girls' Success in a Single-Sex School. Sex Roles, 65, 737-750. Publisher's official version: http://dx.doi.org/10.1007/s11199-010-9904-1. Open Access version: http://kuscholarworks.ku.edu/dspace/.

Table 2

Means and Standard Deviations

Possible

\begin{tabular}{lccc} 
Scale & $M$ & $S D$ & Range \\
\hline Gender typicality & 2.72 & 0.55 & $1-4$ \\
Percentage of male friends & 2.13 & 0.89 & $1-4$ \\
Interest in female friends & 3.17 & 0.69 & $1-4$ \\
Endorsement of gender stereotypes of & 0.46 & 0.26 & $0-1$ \\
$\quad$ activities & & & \\
Endorsement of gender stereotypes of & 1.84 & 0.58 & $1-5$ \\
$\quad$ science and leadership & & & 100 \\
School connection & 3.72 & 0.57 & $0-5$ \\
Academic performance (GPA) & 86.87 & 7.29 & \\
\hline
\end{tabular}


Patterson, M. M., \& Pahlke, E. (2011). Student Characteristics Associated With Girls' Success in a Single-Sex School. Sex Roles, 65, 737-750. Publisher’s official version: http://dx.doi.org/10.1007/s11199-010-9904-1.

Open Access version: http://kuscholarworks.ku.edu/dspace/.

Table 3

\section{Correlations Among Variables}

\begin{tabular}{|c|c|c|c|c|c|c|c|c|c|c|c|c|}
\hline Variables & 2 & 3 & 4 & 5 & 6 & 7 & 8 & 9 & 10 & 11 & 12 & 13 \\
\hline 1 Family income status & $-.17 *$ & $-.41^{* *}$ & -.01 & $.46^{* *}$ & -.06 & $.20 * *$ & $.25 * *$ & -.15 & $-.22 * *$ & .03 & -.08 & -.03 \\
\hline 2 African American & & $-.45 * *$ & $-.30 * *$ & $-.26 * *$ & .01 & -.10 & -.05 & .06 & .08 & -.16 & .06 & -.14 \\
\hline 3 Latina & & & $.18^{*}$ & $-.20 *$ & .12 & .02 & $-.25 * *$ & $.15^{*}$ & .13 & $.23 * *$ & .03 & .13 \\
\hline $\begin{array}{l}4 \text { Connection to single-sex } \\
\text { school }\end{array}$ & & & & $.19 *$ & $.21 *$ & .07 & -.10 & -.12 & $-.20 *$ & $.19 *$ & -.16 & .13 \\
\hline 5 GPA & & & & & .03 & $.56 * *$ & $.37 * *$ & $-.23 * *$ & $-.45 * *$ & .16 & -.10 & -.04 \\
\hline 6 Persistence & & & & & & -.04 & $-.26 * *$ & .07 & -.05 & .09 & -.12 & $.22 * *$ \\
\hline 7 Prior math achievement & & & & & & & $.33^{* *}$ & -.14 & $-.27 * *$ & .12 & -.06 & -.02 \\
\hline 8 Prior reading achievement & & & & & & & & $-.36 * *$ & $-.28 * *$ & .01 & -.09 & -.11 \\
\hline $\begin{array}{l}9 \text { Endorsement of gender } \\
\text { stereotypes of activities }\end{array}$ & & & & & & & & & $.26 * *$ & .05 & .09 & .11 \\
\hline $\begin{array}{l}10 \text { Endorsement of gender } \\
\text { stereotypes of science and } \\
\text { leadership }\end{array}$ & & & & & & & & & & $-.17 *$ & .10 & .01 \\
\hline 11 Gender typicality & & & & & & & & & & & $-.22 *$ & $.24 * *$ \\
\hline 12 Percentage of male friends & & & & & & & & & & & & .03 \\
\hline
\end{tabular}

Note. ${ }^{*} p<.05, * * p<.01$ 
Patterson, M. M., \& Pahlke, E. (2011). Student Characteristics Associated With Girls' Success in a Single-Sex School. Sex Roles, 65, 737-750. Publisher's official version: http://dx.doi.org/10.1007/s11199-010-9904-1.

Open Access version: http://kuscholarworks.ku.edu/dspace/.

Table 4

Multiple Regression Analyses Predicting School Connection

$$
R_{\text {adjusted }}^{2}=.06 \quad R_{\text {adjusted }}^{2}=.10 \quad R_{\text {adjusted }}^{2}=.12
$$

Predictor

Baseline Gender stereotyping Gender identity

\begin{tabular}{lccc} 
& model $\beta$ & model $\beta$ & model $\beta$ \\
\hline Family income status & -.04 & -.05 & -.08 \\
African American & $-.25^{*}$ & $-.21 \dagger$ & $.26^{*}$ \\
Latina & .06 & .11 & .12 \\
Prior math achievement & .08 & .02 & -.10 \\
Prior reading achievement & -.11 & -.16 & -.12 \\
Endorsement of gender stereotypes & & & .07 \\
$\quad$ of activities & & $-.22 *$ & .07 \\
Endorsement of gender stereotypes & & & $-.24^{*}$ \\
$\quad$ of science and leadership & & & \\
Gender typicality & & & \\
Interest in female friends & & & \\
\end{tabular}

Note. $\dagger p=.07, * p \leq .05$ 
Patterson, M. M., \& Pahlke, E. (2011). Student Characteristics Associated With Girls' Success in a Single-Sex School. Sex Roles, 65, 737-750. Publisher's official version: http://dx.doi.org/10.1007/s11199-010-9904-1.

Open Access version: http://kuscholarworks.ku.edu/dspace/.

Table 5

Multiple Regression Analyses Predicting Academic Achievement in First Year at a Single-Sex

School

\begin{tabular}{cccc}
\hline Predictor & $R_{\text {adjusted }}^{2}=.42$ & $R_{\text {adjusted }}^{2}=.50$ & $R_{\text {adjusted }}^{2}=.41$ \\
Baseline & Gender stereotyping & Gender identity \\
& model $\beta$ & model $\beta$ & model $\beta$
\end{tabular}

Family income status

$.30 * * *$

$.16^{*}$

$.18^{*}$

African American

$-.27 * *$

$-.21 *$

$-.26 *$

Latina

$-.24 * *$

$-.19 *$

$-.22 *$

Prior math achievement

$.42 * * *$

$.39 * * *$

$.42 * * *$

Prior reading achievement

.11

.06

.11

Endorsement of gender stereotypes

of activities

Endorsement of gender stereotypes

of science and leadership

Gender typicality

Percentage of male friends

Interest in female friends

.00

Note. ${ }^{*} p \leq .05,{ }^{* *} p \leq .01,{ }^{* * *} p \leq .001$ 
Patterson, M. M., \& Pahlke, E. (2011). Student Characteristics Associated With Girls' Success in a Single-Sex School. Sex Roles, 65, 737-750. Publisher's official version: http://dx.doi.org/10.1007/s11199-010-9904-1.

Open Access version: http://kuscholarworks.ku.edu/dspace/.

Table 6

Logistic Regression Model Predicting Persistence at a Single-Sex School After Two Years

\begin{tabular}{|c|c|c|c|c|c|c|}
\hline \multirow[b]{4}{*}{ Predictors } & Cox \& Snell & $R^{2}=.08$ & & \multicolumn{2}{|c|}{ Cox \& Snell $R^{2}=.23$} \\
\hline & \multicolumn{2}{|c|}{ Baseline } & \multicolumn{2}{|c|}{ Gender stereotyping } & \multicolumn{2}{|c|}{ Gender identity } \\
\hline & \multicolumn{2}{|c|}{ model } & \multicolumn{2}{|c|}{ model } & \multicolumn{2}{|c|}{ model } \\
\hline & Wald & Odds & Wald & Odds & Wald & Odds \\
\hline Family income status & .67 & 1.28 & .01 & 1.04 & .92 & 1.77 \\
\hline African American & .60 & 1.72 & .18 & 1.39 & 1.08 & 3.71 \\
\hline Latina & .75 & 1.69 & .48 & 1.61 & .23 & 1.69 \\
\hline Prior math achievement & .00 & .99 & .85 & .78 & .37 & 1.29 \\
\hline Prior reading achievement & $9.29 * *$ & .49 & $8.88^{* *}$ & .44 & $8.68 * *$ & .22 \\
\hline Endorsement of gender stereotypes & & & .05 & 1.24 & & \\
\hline of activities & & & & & & \\
\hline Endorsement of gender stereotypes & & & 2.52 & .46 & & \\
\hline of science and leadership & & & & & & \\
\hline Gender typicality & & & & & .70 & .46 \\
\hline Percentage of male friends & & & & & $3.72 *$ & .43 \\
\hline Interest in female friends & & & & & $5.27 *$ & 3.59 \\
\hline
\end{tabular}


Patterson, M. M., \& Pahlke, E. (2011). Student Characteristics Associated With Girls' Success in a Single-Sex School. Sex Roles, 65, 737-750. Publisher's official version: http://dx.doi.org/10.1007/s11199-010-9904-1.

Open Access version: http://kuscholarworks.ku.edu/dspace/.

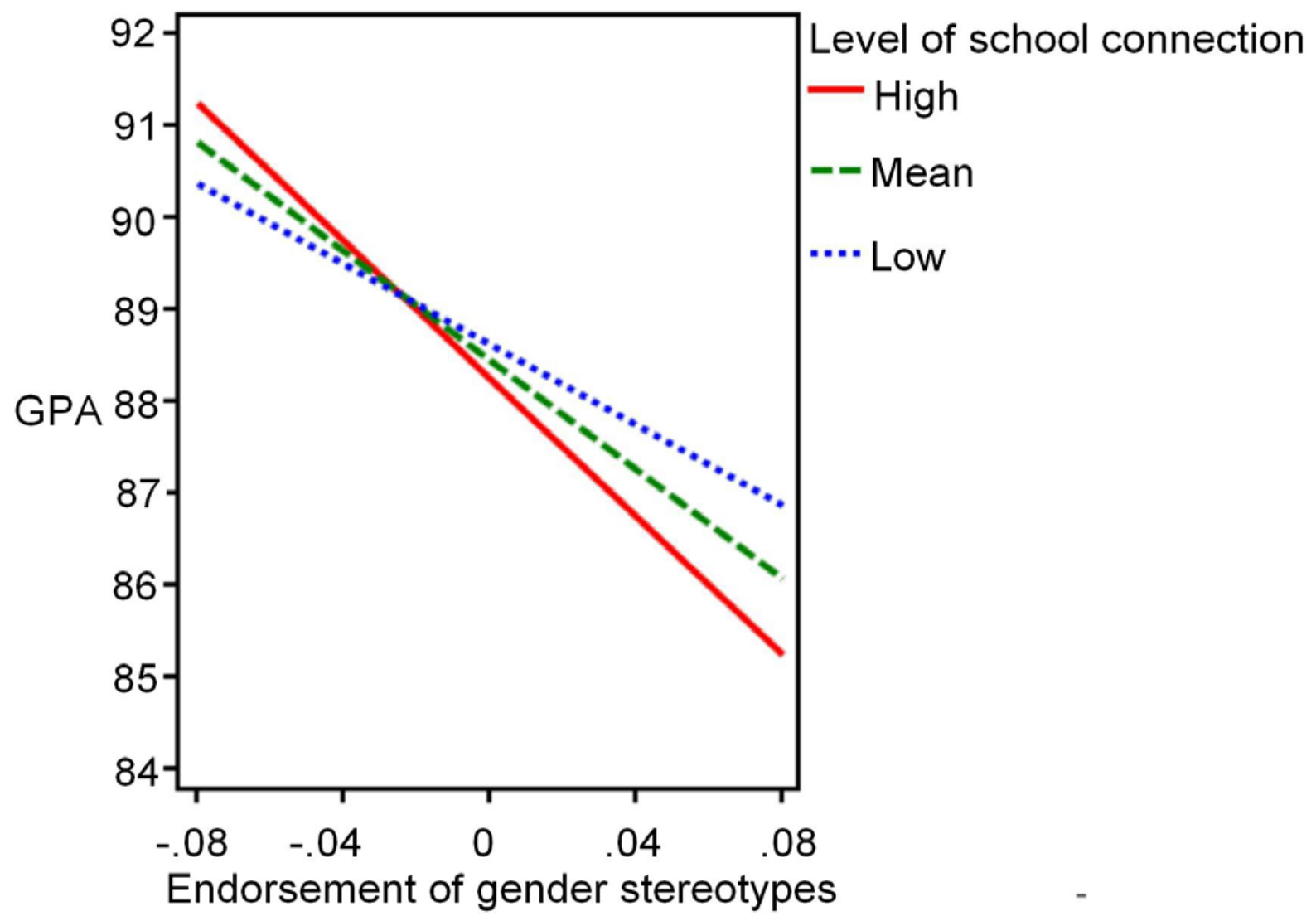

Figure 1. Effects of gender stereotype endorsement of science and leadership (mean centered) on GPA for students with high (1 SD above mean), average (mean), and low (1 SD below mean) levels of school connection. 